http://dx.doi.org/10.18232/alhe.1174

Article

\title{
The Hostile Takeover of the Banco de Comercio of 1954: Collision and Collusion between Mexican Political and Business Elites
}

\section{La compra hostil del Banco de Comercio en 1954. Colisión y colusión entre las elites políticas y empresariales mexicanas}

Andrew Paxman ${ }^{1, *}$ * (D) 0000-0001-6489-4881

${ }^{1}$ Centro de Investigación y Docencia Económicas, Ciudad de México, México.

* Correspondence: andrew.paxman@cide.edu

Abstract. The hostile takeover of the Banco de Comercio in 1954 made way for the era of Manuel Espinosa Yglesias, who would transform the bank into Mexico's largest. However, the episode is more historically notable for what happened behind the scenes: the first large-scale hostile takeover in Mexico; the fact that those who lost control of the bank numbered among the country's most powerful businessmen; the illegal participation as chief purchaser of the foreign citizen William Jenkins, and, as this article argues, the state's approval of the deal on the basis of the distinct political affiliations and relationships of the parties involved. Overall, the episode offers a case study in Mexican state-capital interdependence.

Key words: banks; financial policy; foreign investment; private sector; regulation.

Resumen. La compra hostil del Banco de Comercio en 1954 dio lugar a la época de Manuel Espinosa Yglesias, quien hizo de este banco el más grande de México. Sin embargo, el episodio destaca históricamente más por lo que pasó tras bambalinas: la primera compra hostil de gran escala en México; el hecho de que

CÓMO CITAR: Paxman, A. (2021). The Hostile Takeover of the Banco de Comercio of 1954: Collision and Collusion between Mexican Political and Business Elites. América Latina en la Historia Económica, 28(2), 1-22. DOI: 10.18232/alhe.1174 
los que perdieron el banco se encontraban entre los empresarios más poderosos del país; la participación ilegal del William Jenkins, ciudadano extranjero, como comprador principal, y, como se argumenta en este artículo, la aprobación de la compra por el Estado debido a las distintas afiliaciones y relaciones políticas de los involucrados. En general, el episodio ofrece un caso práctico de la interdependencia entre el Estado y la iniciativa privada en México.

Palabras clave: bancos; política financiera; inversión extranjera; sector privado; reglamentos.

JEL: N26; N46.

Received: February 9th, 2020.

Accepted: September 9th, 2020.

Published: March 22th, 2021.

Acknowledgements: My thanks to Manolo Janeiro of the Fundación Mary Street Jenkins, Puebla, for letting me consult Jenkins' personal records, to my ciDe colleagues Gustavo del Ángel, Pablo Mijangos, and Catherine Andrews for their valuable comments on a draft of this essay, and again to Gustavo del Ángel for sharing with me his interviews of 2006 with former Bancomer shareholders.

\section{INTRODUCTION}

To most historians of Mexico, the spring of 1954 is best remembered for a devaluation of the peso that would prove to be the last until 1976. Much less remembered, but arguably of equal importance to Mexican business history, is a more surreptitious event which took place a month before that April readjustment: the purchase of the country's second-largest bank by a US businessman and his poblano partner. Under the direction of the latter, the Banco de Comercio -today known as BBVA México- would revolutionize Mexican banking by bringing a nationwide network of part-owned subsidiaries into centralized ownership and by pioneering the concept of multipurpose banking, which brought services including mortgages and insurance under one roof. In the process, the bank turned itself into Mexico's most powerful financial institution, in terms of deposits, total assets, branches, and political influence, prior to the bank nationalizations of 1982 (Ángel, 2012).

The March 1954 buyout of the Banco de Comercio is remarkable not only for the subsequent ascent of its innovative chief executive, Manuel Espinosa Yglesias, but also for what went on behind the scenes. First, it constituted what banking historian Gustavo del Ángel has called "[e]l primer takeover hostil de gran escala en México"1 (Ángel, 2007, p. 74). Second, it wrested ownership from several of Mexico's richest and most powerful businessmen. Third, it placed a majority of voting stock in the hands of a foreigner, the US expatriate industrialist William O. Jenkins, who -contrary to previous accounts of this episode- retained de facto control until his death in 1963; this was in contravention of Mexican law. ${ }^{2}$ Finally, so this article will argue, the takeover received the blessing of the government, despite its illegality and the complaints of leading founder-owners, due to the perceived needs and personal relationships of the parties involved. This last point is crucial,

1 “The first large-scale hostile takeover in Mexico" [Author's translation].

${ }^{2}$ Previous accounts of the takeover have Espinosa gaining majority ownership following a swift asset exchange with Jenkins in 1955 (Ángel, 2007, p. 79f; 2012, p. 268f; Espinosa, 2000, pp. 24-30). 
for it substantiates the often-commented but under-documented role of the post-revolutionary Mexican State in shaping the course of private enterprise for mutually-beneficial and sometimes monopolistic purposes.

The episode is thus an example of interdependence between State and capital in modern Mexico. While all social scientists examining the relationship between the two entities have ascribed great power to each, some give the state the upper hand (Camp, 1989; Elizondo, 2001). Others argue or imply that, notwithstanding famous acts of expropriation, the business elite has had greater long-term sway (Concheiro, Gutiérrez \& Fragosa, 1979; Maxfield, 1990; Saragoza, 1988). This study offers an illustration of how the relationship between the two is one of symbiosis.

As the Institutional Revolutionary Party (PRI) gradually consolidated its hegemony in the 1940s and 1950s, leading politicians and functionaries believed it was crucial for national stability that challenges to the party's dominance and criticisms of its policies should be minimized. After ten years of revolutionary war, another eighteen years of frequent rebellion, and a 1940 presidential election marred by bloody clashes, the PRI gave prime importance to the reconciliation of classes and the "ideology of national unity" (Navarro, 2010; Pellicer \& Reyna, 1978, p. 7).

First, opposition parties were to be tolerated merely to the extent that they offered token evidence of a plural democracy. Owing to their great confidence in their abilities and to geopolitical Cold War tensions, as evidenced in political strife and military regimes in countries to the south, senior priistas wished to contain surging threats from both right and left; that is, they regarded an all-powerful, corporatist, non-military PRI as the one institution capable of juggling the interests of Mexico's disparate constituencies and maintaining the peace (Alexander, 2016, pp. 89-91, 166f; Krauze, 1997, pp. 205-208, 216-218; Pellicer \& Reyna, 1978, pp. 7-10). Second, criticisms of the ruling party to were to be restricted to the margins of public discourse and limited official channels. Hence the mainstream press was incentivized, by the stick of forced closures but more often the carrot of subsidies, to toe the official line (Smith, 2018). And hence the business elite, the one socioeconomic group not formally incorporated into the PRI, was expected -as the employer of hundreds of thousands of voters - to keep its differences of political opinion to itself. Only chambers of commerce, affiliated by law to the state, subject to its interventions, and led by businessmen of middle rather than senior rank, felt free to (selectively) voice public complaints (Pellicer \& Reyna, 1978, pp. 22-25; Story, 1986, ch. 4). Most of the time, the unwritten prohibition worked. As Roderic Camp put it, as regards the 1920s to the mid-1970s, "entrepreneurs have been notable for avoiding public exposure" (Camp, 1989, p. 246).

In the case of the 1954 Banco de Comercio purchase, this essay argues that Treasury (Hacienda) minister Antonio Carrillo Flores permitted Jenkins to own the bank chiefly for two reasons: because its principal original shareholders were activist members of the conservative National Action Party (PAN), whereas Jenkins had a record of loyalty to the PRI; and because some of those panista shareholders were vocal critics of state-led development. As a supplementary factor, during the year after Jenkins became majority shareholder but before Espinosa took over at the bank, the American repeatedly proved his usefulness and loyalty to the regime.

Altogether, the episode illustrates the importance of politics to business history. It also exemplifies the rarely detailed role of interpersonal relations within the state-capital dynamic. Personal relations feature little in the historiography because post-revolutionary Mexican business history has largely consisted of three models that methodologically tend to exclude them. The first is a structural approach that treats the business class as a collective, acting as industrial sectors or regionally-based groups and promoting its interests via chambers of commerce and associations 
(Concheiro et al., 1979; Gauss, 2010; Schneider, 2004; Story, 1986; Valdés, 1997; Vidal, 2000). ${ }^{3}$ The second is an enterprise-specific model that, usually in the absence of access to company archives, fleshes out what is known publicly about the firm with generalizations about its relationship to state and society drawn from political science (chiefly, until the 1990s, from Marxism); given source limitations, such studies lend themselves to articles in collections rather than monographs (Jacobo, Luna \& Tirado, 1989; Pozas \& Luna, 1991; Romero-Ibarra, 2006). The third common approach relies on the cooperation of the companies themselves, their chief executives, or their descendants, who usually grant very limited access to archives and encourage the authors -whom in many cases they have contracted- to emphasize entrepreneurialism and de-emphasize state actors, except as obstacles to be overcome (Águila, Soler \& Suárez, 2007; Fuentes-Berain, 2007; Recio, 2016; Trejo, 2013). Del Ángel's history of BBVA Bancomer (2007), though written with unusual insight for an official work and also somewhat attentive to the role of functionaries, is such a book. Further, its account of the Jenkins-Espinosa takeover omits the role of party politics and the influence of the American in ensuring its approval.

The episode also suggests a lesson about the state-capital symbiosis after 1952. During the sexenios of Manuel Ávila Camacho and Miguel Alemán, relations between the two sectors were characterized to a great extent by crony capitalism, in the traditional sense of business leaders receiving special favours from senior politicians (operating concessions, regulatory waivers, special tax breaks, penalizing of rivals, etc.) in exchange for a pay-off, campaign donation, or covert stake in their business (Alexander, 2016, pp. 69-72, 167-173; Fernández y Paxman, 2021, pp. 72-78; Krauze, 1997, pp. 120-124; Niblo, 1999, ch. 4; Paxman, 2016, chs. 7-9). But as of the era of Adolfo Ruiz Cortines, those relations became less corrupt -at least, much less visibly so- and more convenient to the general perpetuation of PRI rule and the cultivation of great enterprises (Fernández y Paxman, 2021, pp. 79-81; Krauze, 1997, pp. 191-194). This marked something of a return to the inter-institutional arrangement of the 1920s, except that the motives were now less ones of survival and more ones of dominance (Maurer, 2002, ch. 8; Maxfield, 1990, ch. 2; Zebadúa, 1994, chs. 4-7).

Absent access to BBVA Bancomer company archives, this article relies on a wide range of primary and secondary sources to reconstruct the episode and its context. The former include the personal records of Jenkins, the correspondence of Espinosa Yglesias, an extensive interview with Carrillo Flores by Espinosa's daughter Amparo, the archive of the federal secret service (Dirección Federal de Seguridad), the Public Property Registry of Puebla (where Jenkins lived), and newspapers of the era.

\section{The Banco de Comercio and Jenkins' growing Shareholding}

The origins of the Banco de Comercio date from 1932, when Salvador Ugarte, a banking executive from a middle-class provincial family, recruited several wealthy partners to found a bank in Mexico City (Ángel, 2007, pp. 21-28). In a feat unrivalled in the post-revolutionary banking sector, Ugarte built up its business so that it quickly overtook the Bank of London and Mexico, founded in 1864. By 1954 it boasted assets of 873000000 pesos, still some way behind the 1.88 billion of the Banco Nacional de México (today's Citibanamex) but more than twice those of third-placed London and Mexico (today's Santander México) (Anuario Financiero de México, 1941, 1955).

${ }^{3}$ By contrast, Camp (1989) and Maxfield (1990) take unusual note of interpersonal relations. 
Among the bank's chief backers and board members were three powerful and prestigious financiers who would join with Ugarte in forming what became known as the BUDA Group, an informal alliance rather than a conglomerate, the label being an acronym of their surnames. These were the silver magnate Raúl Bailleres, one of Mexico's richest men, Ugarte himself, the bank's chairman, Mario Domínguez, who with his brother Augusto separately owned another bank, the Banco General de Capitalización, and Ernesto Amescua, who headed insurance company Seguros La Nacional (Ángel, 2007, pp. 25-28, 73f). Collectively, the BUDA quartet had grown accustomed to working with the state in shaping financial policy, which they had begun to do in the Cárdenas era. They were also key industrial players, their assets including the Cervecería Moctezuma (Ángel, 2007, p. 74; Hamilton, 1982, pp. 211f, 294-297; Recio, 2004, p. 300). In terms of wealth, Jenkins inhabited the same exalted plane as these men; in terms of reputation, he lurked some way below (Paxman, 2016). So it must have been a shock to the financial elite when Jenkins, with Espinosa Yglesias acting for him, emerged in the mid-1950s as the bank's majority owner. ${ }^{4}$

The takeover built upon nearly 20 years of stock accumulation, often by stealth. The story started in Jenkins' adoptive home of Puebla. From the time of the bank's founding, Ugarte and his right-hand man Eustaquio Escandón had envisioned a series of provincial affiliates to the main enterprise in Mexico City that would be majority-owned by local industrialists; the combination of the mother bank's acumen and capital, along with local knowledge of each business terrain, would help the Banco de Comercio expand quickly nationwide (the model differed from that of the Banco Nacional de México, which involved wholly-owned local branches). The first affiliate to be established, in February 1934 and with start-up capital of 250000 pesos, was the Banco Mercantil de Puebla (вмP) (Ángel, 2007, pp. 27f, 37-41). ${ }^{5}$ But in less than two years disaster struck, as the BMP fell victim to a fraud so grave that its local backers, who together held two-thirds of its shares, decided they should liquidate the company. Ugarte, however, was determined to save his first affiliate, and in December 1935 he travelled to Puebla to seek new infusions of capital. After the local shareholders baulked at the sums needed, Ugarte found a white knight in Jenkins, who stepped in to save the bank (Espinosa, 2000, p. 35f).

The American had made successive fortunes in three sectors: textiles during the late Porfiriato and early years of the Revolution; speculation in real estate during the Revolution's latter years and early 1920s, and sugar planting, centred on the Puebla estate of Atencingo. By 1935 he was probably the richest industrialist in the state and its largest private-sector employer. The following year he would make a campaign donation to gubernatorial candidate Maximino Ávila Camacho of 40000 pesos (equivalent to US\$ 200000 today), far in excess of what Puebla's traditional business elite would individually contribute (Paxman, 2016, chs. 5 \& 7).

Jenkins' motives for taking a stake in BMP are not known, but they can be deduced. First, largescale sugar planting was a capital-intensive business; under Jenkins' direction, Atencingo had acquired and annexed seven neighbouring estates, all supplying cane via a private rail line that he had built to the central mill, and in August 1935 he had acquired a ninth estate, Hacienda Raboso. Insider-lending among principal shareholders was common in the banking sector. ${ }^{6}$ So, having

\footnotetext{
4 "According to one source, after Espinosa Yglesias entered the bank it was suddenly discovered that the majority of shares were controlled by Jenkins" (Hamilton, 1982, p. 296, italics mine).

${ }^{5}$ Libro 1 de Comercio, t. 8, núm. 169 (February 13, 1934). Registro Público de la Propiedad, Puebla (hereafter RPPPuebla).

${ }^{6}$ Insider lending was a routine and rational practice within Mexican banking at the time, as it had been in early stages of banking in other countries (Ángel, 2007, pp. 63f; Chavarín, 2010, pp. 22f, 38-41; Haber, 1991).
} 
ready access to cheap credit would facilitate the integration of Raboso and further improvements at Atencingo; it would also help his business meet its obligations in years when demand for sugar fell. Second, the accession of Lázaro Cárdenas the year before seems to have prompted Jenkins to diversify his holdings, given the vulnerability of Atencingo to the new president's priorities repeatedly sounded during his marathon election campaign - of land reform and the nationalizing of the economy. In November 1935 Jenkins had returned to the textile sector with the acquisition of an important mill in Tlaxcala, and over the next three years he would invest in an auto assembly plant and his first of many movie theatres (González, 1979, pp. 236-243; Paxman, 2016, pp. 290-304). Investing in a bank both conformed to this diversification plan and expedited it.

To date, historians' accounts of Jenkins' investment in BMP have depended on a passage in the memoirs of Espinosa, which are not always accurate regarding details and dates (Ángel, 2007, pp. 39-41; Paxman, 2016, p. 301). However, the accounting books of Jenkins' main venturecapital vehicle, Compañía de Inversiones de Puebla, S. A. (CIPSA), confirm the American's purchase of BMP shares. No mention is made of share purchases in 1935 or 1936, which suggests that Jenkins' initial response to BMP's crisis was to make it a loan, presumably a convertible one. But new purchases are recorded for 1937, of 100000 pesos of BMP stock and another 155000 pesos of Banco de Comercio stock. In subsequent years, Jenkins bought further modest but cumulatively significant shareholdings in the parent bank: investing 82000 pesos in 1938, 79000 pesos in 1940, and 136000 pesos in 1941. ${ }^{7}$ This incremental strengthening of his position in the Banco de Comercio would continue over the next decade.

Around 1942, Jenkins traded his stake in BMP for a much greater holding in the Banco de Comercio, when the latter's board felt a need to assume majority-ownership of its largest affiliate, due to resistance among the local partners to its directives. At the time, Ugarte told the board that they had nothing to fear from Jenkins -despite his reputation as a voracious operator- as the American had no desire to extend his business interests beyond Puebla. In actual fact, Jenkins had begun investing with Espinosa Yglesias in movie theatres in Guadalajara and elsewhere and would shortly invest in a major new chain of theatres, Compañía Operadora de Teatros (COTSA), in Mexico City (Anuario Financiero de México, 1943; Espinosa, 2000, p. 36f; Paxman, 2016, pp. 298f, 318f). Since theatre construction required major outlays of capital, and again, since insider-lending was standard practice, it would have benefitted Jenkins not only to gain a minor stake in the Banco de Comercio, but also to seek a bigger one. That same year, he invested another 600000 pesos in purchases of its stock. ${ }^{8}$

In 1945, Jenkins further increased his position in the bank when a major client, Eustaquio Escandón's recently-founded Nacional de Drogas, suffered a post-war collapse in revenues as the market for pharmaceuticals was flooded with competing product. As the bank saw its solvency threatened, it issued new shares to raise capital, and Jenkins bought heavily. He went on to buy further shares from the families of two of the founding investors, when inheritance disputes occasioned their sale. Subsequent capital increases by the bank, funding its expansion as it sought to catch up with the Banco Nacional de México, allowed Jenkins yet more purchases (Ángel, 2007, p. 78). Many such acquisitions began to be made via a private investment bank, Financiera de

${ }^{7}$ Compañía de Inversiones de Puebla S. A. (CIPSA), Libro Mayor II (1935-1939, pp. 41, 63), Libro Diario (1938-1943, pp. 113, 146), Fundación Mary Street Jenkins (hereafter cited as FMSJ), Puebla. In 1936, the BMP raised its capital to 450000 pesos, while Jenkins' 100 000-peso purchase implied a $22 \%$ stake, in addition to whatever de facto stake he held on the basis of his 1935 loan; Libro 3 Auxiliar de Comercio, t. 21, núm. 67 (November 16, 1936), RPP-Puebla.

${ }^{8}$ CIPSA, Libro Diario (1938-1943, pp. 170, 174, 177, 178), FMSJ. 
Puebla S. A., which Jenkins set up in 1945-1946 with 2000000 pesos in capital. Managed by a bilingual accountant, Luis Puente Mijares, the Financiera did not list Jenkins among its founder investors, only his closest business partners: Espinosa, Alarcón, Rómulo O'Farrill, and two others. ${ }^{9}$

The BUDA Group may have been unaware of many of these moves. First, since the 1930s, Jenkins had made all of his investments via prestanombres. Second, shareholdings were often only vaguely known, as what mattered was the physical possession of the share certificates, which bore the simple inscription "to the bearer"; hence, it was fairly easy for buyers to keep purchases secret. Third, Jenkins had an inside ally in the person of Armando H. Hernández, a subdirector of the bank in charge of provincial operations. Hernández had previously worked at the Banco Mercantil de Puebla, where he began a lifelong friendship with Jenkins, and he too purchased Banco de Comercio shares when they became available on Jenkins' behalf (Ángel, 2007, p. 78; Paxman, 2016, pp. 235-238; Senderos, 2006).

\section{A HOSTILE AND CUNNING TAKEOVER}

By 1950 Jenkins owned $41 \%$ of Banco de Comercio stock, making him much the biggest single shareholder, and that year he placed Espinosa on the bank's board to represent him (presumably without revealing exactly how much stock he owned). The bank's other directors reconciled themselves to the presence of these outsiders. It is unlikely that they would have thought themselves threatened because legal precedent restricted foreign control of banks. Owing to security concerns during the Second World War, the government decreed in July 1944 that at least $51 \%$ of a Mexican company's shares be held by Mexican nationals. The restriction was renewed after the close of hostilities and would remain in effect until 1989, when president Carlos Salinas effectively annulled it. The decree had allowed for exemptions, but it was unlikely that any would be granted in the case of a bank, given the public memory of how the banking sector before the Revolution had been dominated by foreigners in cahoots with Porfirian crony-capitalist elites (Maurer, 2002, chs. 2-4; Niblo, 1995, pp. 214-217; Zamora, 2004, pp. 576-579). ${ }^{10}$

Further, on putting Espinosa on the board, Jenkins had subscribed to its gentlemen's agreement that no one shareholder would seek a majority stake. One director, Manuel Senderos, later put it: "Jenkins, a pesar de que se le atribuía cierta reputación, era un hombre recto con sus socios. Sabíamos que respetaría el acuerdo entre los consejeros de no tomar el control del banco, al menos él en lo individual"11 (Ángel, 2007, pp. 74, 79).

As Senderos' reminiscence implies, the board did not count on the machinations of Espinosa Yglesias. By the early 1950s, the ambitious poblano was eying pastures greener than the box office. Profit margins for the huge coTsA chain of several hundred movie theatres that he co-owned with Jenkins began a gradual decline after the December 1952 imposition of price caps on tickets in Mexico City; public appetite for Mexican films, of which Espinosa was an important financier, was also waning. Banking likely drew his attention because he had already proven himself an able financial manager in the high-cost business of theatre-building and because the sector might allow him the chance to step out from the American's shadow and forge a distinct career. The business

${ }^{9}$ Libro 1, t. 12, núm. 90 (March 18, 1946), RPP-Puebla, México; Puente (2018); Espinosa (1946).

${ }^{10}$ Diario Oficial (July 7, 1944, pp. 2-4).

11 "Jenkins, in spite of the certain reputation attributed to him, was an upright man with his business partners. We knew he would respect the board members' agreement not to take control of the bank - at least, he himself would do so" [Author's translation]. 
of film exhibition was also beset by labour tensions, filmmaker criticism of the Jenkins Group, and an uncomfortable personal rivalry between Espinosa and Jenkins' other main partner in the sector, Gabriel Alarcón (Águila et al., 2007, pp. 123-149; Paxman, 2018).

Acting behind Jenkins' back, Espinosa sought a weak link within the Banco de Comercio shareholder group. Manuel Senderos, a young man who had inherited a $10 \%$ stake, would be the target; his share would suffice to place majority-control of the bank in Jenkins' hands. Espinosa offered him a premium, 9500000 pesos for a holding worth just under 8000 000, and he did so at a time when Senderos was prioritizing other businesses. Deceptively, Espinosa told him that the buyer was the Mary Street Jenkins Foundation, a charitable institution that Jenkins was in the process of establishing in memory of his late wife, which was seeking investment opportunities for its endowment. The purchase, effected in or shortly before March 1954, put Mexico's number-two bank in the American's hands (Espinosa, 2000, pp. 22-26, 38-42). ${ }^{12}$

Jenkins was surprised and unhappy about the purchase. His partner of sixteen years had deliberately effected a deal that put him, as a foreigner, in a position of illegal control. Jenkins had a history of evading taxes and skirting laws, but nothing compared to the audacity of owning a major bank. Following a barrage of negative press in early 1953, in which he was assailed for his monopolistic practices in the film industry, Jenkins was no doubt wary of becoming the target of another nationalistic onslaught (Espinosa, 2000, p. 25f; Paxman, 2016, p. 384f).

Espinosa downplayed the issue in his memoir, but he forced his partner's hand: Jenkins would have to relinquish his ownership of the Banco de Comercio, yet the financial advantages to his movie-theatre circuits and other businesses of ready access to the bank no doubt meant that he would wish to keep it within his sphere of influence. Espinosa, who had proved his business savvy by building COTSA into the giant of the film exhibition business, was indeed the best man to run it. It would therefore fall to the poblano to assume nominal control of the bank. Becoming its "director" in April 1955 -a newly-created post that placed him below the cEO, Ugarte, but above the general manager, Aníbal de Iturbide- Espinosa would rule the institution for twenty-seven years (Ángel, 2007, p. 80f; Espinosa, 2000, pp. 27-30).

\section{TENSIONS WITH PARTNERS AND HELP FROM THE TREASURY}

During his first two years as director, Espinosa faced resistance from the founding directors, but he would find an ally in Treasury minister Carrillo Flores. Raúl Bailleres, previously the bank's largest single investor, was angry that majority ownership and executive power were held by a single person. From the start, the bank's success had owed much to a carefully maintained equilibrium, its founders all accountable to one another and day-to-day operations led by an independent general manager, Iturbide. Espinosa's assumption of near-dictatorial control seemed to him a huge backwards step for corporate governance. Worse, Espinosa was not even a banker, but an arriviste from the film industry. Bailleres tried to force Espinosa to resign as director and sell his shares by threatening the mass exit of most of the board, a move that would induce major clients to take their business to other banks. Assured that he had Jenkins' backing, Espinosa refused to back down (Espinosa, 2000, pp. 40-42).

${ }^{12}$ Jenkins to Espinosa, Puebla (March 16, 1954), caja 31, exp. 28, Archive of Manuel Espinosa Yglesias (hereafter, MEY). 
Tensions quickly rose again, now between Espinosa and Iturbide. The general manager approved a multi-million-dollar purchase of bonds from board member Carlos Trouyet's cellulose company without consulting Espinosa; this prompted the poblano to request Iturbide's resignation. It was more the size of the sum, than the then-routine practice of insider lending, that upset Espinosa (Espinosa, 2000, pp. 46-49). In June 1955, Iturbide quit, as did Trouyet, and while the mainstream press was too deferential to report the scandal, the independently-minded leftwing newspaper El Popular happily did so. "La renuncia de Aníbal de Iturbide crea al Banco de Comercio un serio problema", ${ }^{13}$ ran the headline; the article claimed many clients had withdrawn their deposits. ${ }^{14}$ An exodus was understandable, for Iturbide, who was president of the Mexican Bankers' Association, and Trouyet, a millionaire multi-industrialist, were respected and well connected. Together they joined the Banco Comercial Mexicano (всм; todays' Scotiabank México), respectively as director and board member. всм had been founded in 1934 by the Chihuahuabased Vallina family and was chaired by former Treasury minister Eduardo Suárez. The troubles at the Banco de Comercio evidently hampered its ability to harness the economic boom of 1955; while the Banco Nacional de México and всм both saw their assets grow by $36 \%$, it registered more modest asset growth of 24 \% (Ángel, 2007, p. 81f; Anuario Financiero de México, 1955, 1956).

In 1956 a third crisis erupted. Seeking to turn the Banco de Comercio into a multifaceted financial institution, Espinosa wanted Bailleres and Senderos to sell to it the investment bank and insurance company they respectively owned. At the same time, tensions were worsening between the poblano director and the more independent-minded board members, as Espinosa became more imperious and threatened their business interests. In November, Bailleres, Senderos, and eight other directors resigned in unison, some then accepting the invitation of Iturbide and Trouyet to join the всм (Ángel, 2007, pp. 82-84). Making the split more emphatic, Ugarte and Espinosa in turn resigned as directors of companies owned by Bailleres, Senderos, and their allies, and the BCM took out a full-page ad announcing its new board. ${ }^{15}$

Commented El Popular: thanks to the fuerza bruta of Jenkins, Espinosa, and Alarcón, the Banco de Comercio had already lost its alma, Iturbide. Now it was seeing the exit of Bailleres, Domínguez and Amescua which endangered the accounts of its clients, sowed doubt among the public, and thereby threatened the country's economy. ${ }^{16}$ The Treasury might well intervene, the paper continued, because the development of Mexico could not be put at risk by Jenkins, whom it likened to the mafioso $\mathrm{Al}$ Capone. ${ }^{17}$

There was indeed intervention by the Treasury, but it did not take the form that El Popular advocated. Behind the scenes, Carrillo Flores had been giving Espinosa moral support and practical guidance since his election as Director. According to Espinosa, Carrillo Flores, Banco de México chief Rodrigo Gómez, and Government (Gobernación) minister Ángel Carvajal all expressed their confidence in his leadership, in part because Ugarte remained president and because Armando Hernández remained subdirector, which gave the bank operational continuity. In fact, the government insisted that the 76-year old Ugarte, regarded as an elder statesman of the banking sector, stay on. Hernández, for his part, had a genius for coordinating relations with existing regio-

18 “Aníbal de Iturbide resignation a serious problem for the Banco de Comercio" [Author's translation].

${ }^{14}$ El Popular (June 6, 1955, p. 1).

${ }^{15}$ El Universal (November 15, 1956, pp. 1, 7, 28).

16 This was not entirely alarmism; directors then played a crucial role in bringing major clients to any bank (Ángel, 2007, pp. 26, 81.)

${ }^{17}$ El Popular (November 15, 1956, pp. 1, 3). 
nal affiliates and recruiting new ones. Then in 1956, when three of the four members of the BUDA Group -all but Ugarte- and various of its allies departed, Carrillo Flores recommended respected industrialists to replace them, including Juan Sánchez-Navarro, a senior executive at the Cervecería Modelo, who would become the great ideologue of the private sector (Ángel, 2007, pp. 34, 84-86; Espinosa, 2000, pp. 49-52). Thus, just six days after вСм trumpeted its welcoming of Bailleres and company, the Banco de Comercio was able to announce its own renewed board, via a prominently-placed story (almost certainly a paid-for gacetilla) on the front page of Excélsior. ${ }^{18}$

Carrillo Flores and his fellow ministers would prove correct in their confidence in the new management, at least in the long run. During Espinosa's early years at the helm, the defections of board members and major clients to the Bсм appear to have slowed the growth of the Banco de Comercio. Whereas in 1954 its assets had been $47 \%$ the size of those of the Banco Nacional de México and 2.6 times the size of those of всм, in 1963 its assets were just $38 \%$ as large as those of the Banco Nacional de México and just 1.6 times those of всм. On the other hand, as Espinosa prioritized putting his personal stamp on operations, a key dimension of which was to rebrand all the regional affiliate banks as Banco de Comercio (de Puebla, etc.) and to accelerate the founding of new affiliates, he gave the bank great visibility at the national level. These affiliates had numbered thirteen by 1951, since when no new ones had been created. Espinosa restarted the expansion programme with unprecedented vigour, founding three regional banks and acquiring six others between December 1955 and November 1956 (Ángel, 2012, pp. 270-273; Anuario Financiero de México, 1955, 1964). Owing to his drive and vision, the Banco de Comercio would become Mexico's largest bank in 1977, when all the regional affiliates and financial sister companies were rolled into a single multipurpose bank, renamed Bancomer (Espinosa, 2000, pp. 106-122).

As for Jenkins, with the Banco de Comercio ready to serve his every investment need, he no longer had use for his Financiera de Puebla, and in 1955 he sold the company (presumably to the bank). ${ }^{19}$ Without access to BBVA Bancomer records, one cannot know exactly how co-ownership served Jenkins, but one can deduce from his record. In 1957, for example, the Jenkins Group bought out their only remaining major rival in the film exhibition business, Abelardo Rodríguez, who owned fifteen theatres in Mexico City, two in Puebla, and a chain of 50 in the northwest. Around the same time, Jenkins initiated his final major venture by starting to buy land in Apatzingán, Michoacán, in order to create a cotton plantation (Paxman, 2016, chs. 9 \& 10).

\section{Behind the scenes: Political motives}

The long-term success of Espinosa at the helm of the Banco de Comercio can hardly have been predicted. He had no banking experience beyond his relatively recent role as a board member. Nor did Jenkins, despite his nearly two-decade involvement as a shareholder. His record as a venture capitalist was impressive: backing Espinosa and Alarcón, he had financed the development of a film exhibition empire that controlled close to $80 \%$ of the movie theatres in the country. But he was now in his mid-70s and slowing down (Paxman, 2016, ch. 10).

Why did Carrillo Flores allow a semi-retired, controversial American and his inexperienced proxy to take ownership of the Banco de Comercio, Mexico's second-largest? Why do so in the face of resistance from its wealthy and well-connected owners and in contravention of the legal

${ }^{18}$ Excélsior (November 21, 1956, pp. 1, 9).

${ }^{19}$ Puente (2018); Puente (1969). 
restriction upon foreigners taking majority stakes in Mexican firms? Irrespective of the question of whether it was in fact Jenkins or Espinosa who owned the majority holding, Carrillo Flores could have reversed the takeover on the grounds that the then-current 1941 General Law of Credit Institutions gave the Treasury the right to award concessions to banks, "apreciando la capacidad técnica y moralidad del solicitante". ${ }^{20}$ And while it might be argued that Jenkins and Espinosa were not concession-seekers ("solicitantes") but buyers, precedent suggested that the buy-out were still subject to approval, as the first banking license awarded under this legal regime (to Luis Montes de Oca's Banco Internacional) specified that no transfer of ownership would be permitted without the consent of the Treasury. ${ }^{21}$

The answer to this puzzle has three components. First, the BUDA Group and several of its allies at the bank were active members of leading opposition party the PAN. Indeed, PAN founder and leading ideologue Manuel Gómez Morín had chaired the Banco de Comercio board in its early years (Ángel, 2007, pp. 26-28, 34). The PAN called for a much more free-market path of development than the state-centred model pursued by the PRI, which had already nationalized the oil sector and the railways and was eying further strategic industries. Soon after its founding in 1939, the PaN had played an important role in the presidential election of 1940 by informally backing opposition candidate Juan Andreu Almazán, who carried out a formidable campaign against ruling-party candidate Manuel Ávila Camacho. The official tally of votes, which fraudulently gave Ávila Camacho $94 \%$ versus Almazán's $5 \%$, disguised the close-run nature of the contest. Over the subsequent decade, the PAN grew little as an electoral force, and it would refrain from fielding a candidate in the election of 1946, although it did win four seats (out of 147) in the Chamber of Deputies (Loaeza, 1999, pp. 218-223, 235; Sherman, 1997, ch. 8). But the PRI remained vigilant, both about the potential threat the PAN posed to its hard-won hegemony and about the role of the BUDA Group and its allies in bankrolling the party.

To be specific, in 1949, president Alemán entrusted his newly-created secret service, the Federal Security Directorate (DFS), with spying on the BUDA Group. DFS agents fingered Iturbide and Escandón as well as the BUDA quartet as PAN members. In language that reflected state fears of a resurgent PAN, DFS agents concluded that BUDA not only sustained the party financially, but also was rolling out an anti-government campaign of which a recent open letter to Alemán was just the initial shot. Some of the agents' language was excessive, like their allegation that BUDA controlled the banking sector, which ignored the greater strength of the Banco Nacional de México. But evidence of its influence abounded. ${ }^{22}$

While the BuDA foursome themselves kept a low profile, they had succeeded in placing loyalists at the head of the National Banking Commission, a regulatory board distinguished for its culture of secrecy, and various business associations. These included the Confederations of Industrial Chambers (Concamin) and of National Chambers of Commerce (Concanaco), the Bankers' Association, the Insurance Association, and the elite Business Owners' Association (Coparmex). Such groups had a record of lobbying hard against tax increases, and in 1949 -so DFs agents allegedeach was using its member network to distribute PAN propaganda and build a vote-gathering apparatus. BUDA allies were encouraging members of the pro-government Manufacturing Industry

20 “Taking into account the technical ability and moral standing of the concession seeker" [Author's translation].

21 Arts. 2 and 5 (May 31, 1941, pp. 2, 44), Diario Oficial.

${ }^{22}$ Manuel Basail de la Vía \& José Manuel Vertiz to director, Mexico City (January 10, 14, 1949), exp. 12-17-949, pp. 4-6, 49-53, Dirección Federal de Seguridad, Archivo General de la Nación (hereafter, DFs-AGN); index card (August 26, 1949), exp. 25-12-949, p. 3, DFs-AGN. On the DFs as tool of political control, see Aguayo (2001, ch. 3). 
Chamber (CANacintra) to leave, and so far the members from the cement and iron industries had done so. The Banco de Comercio, specifically, was using its regional network of affiliate banks as tentacles of the party and acquiring businesses whose employees could be converted into PAN loyalists via the pressure of company unions. Later that year, the bank's Mexico City flagship branch mailed PAN flyers to account holders along with their statements. ${ }^{23}$

The PAN failed to alter the course of the 1952 election. The greater threat to the PRI that year came from the left, in the candidacy of general Miguel Henríquez, who according to official results gained $16 \%$ of the vote, compared with $8 \%$ for the PAN's Efraín González Luna (Servín, 2001, p. 364f). Nevertheless, there remained cause for concern. No ruling-party candidate had gained as low a proportion of the vote as Ruiz Cortines' $74 \%$. Further, the party's annual convention in 1953 drew headlines for the unusual degree of internal dissent on display. General Jacinto B. Treviño, a senator and former cabinet minister, caused great commotion with a fiery speech about the direction of the Revolution. He claimed that the PRI had lost its way and emphasized its fixing of elections and the self-enrichment of officials (Niblo, 1999, p. 237).

Whatever the relative strength of the PAN, there was also a principle at stake. The BUDA Group had for fifteen years involved itself in politics, an arena that according to PRI ideology should be free of the influence of business elites, which in the party's revolutionary discourse constituted "the reaction". According to the PRI's corporatist logic, when an industrialist had something to say about policy, he should do so via the sanctioned channel of his respective chamber of commerce, a practice formalized by the 1936 Ley de Cámaras (Camp, 1989, pp. 19, 33; Elizondo, 2001, pp. 86, 92f).

In light of all these precedents, the official decision to allow the American and his poblano business partner to buy the country's number-two bank makes sense, for Jenkins was a proven loyalist of the PRI and friend to party elites. He had made substantial donations and loans to its candidates, not only Maximino Ávila Camacho in 1936, but also Manuel Ávila Camacho, in the presidential campaign of 1939-1940, and Miguel Alemán, in the presidential campaign of 19451946. More recently, he had subsidized an ambitious school-building programme in the state of Puebla and public works in Puebla City. Further, although Jenkins had never obtained Mexican citizenship, he had created and operated businesses in Mexico for half a century and reinvested -rather than repatriating to the United States- almost all of his profits (Paxman, 2016, chs. 7-10). In other words, he was not, in the usual sense of the phrase, a foreign investor.

Was the affiliation of the BUDA Group to the PAN the only issue? In the mid-1950s, although the PRI had indeed been navigating troubled waters, its problems owed more to internal tensions than to the PAN. Within the long trajectory of the latter as an opposition party, Soledad Loaeza describes the years 1940-1961 as "the crossing of the desert", with the years 1949-1961, more specifically, those in which the PAN became a Catholic-dominated ghettopartei of limited public appeal. Its presence in the Chamber of Deputies, gained with four seats in 1946, barely grew over subsequent years, obtaining four seats again in the elections of 1949, five in 1952, and six in 1955 (out of a total of 162). Altogether, there is little evidence, either documentary or circumstantial, that Ruiz Cortines or his cabinet were worried about the PAN as a political force, even though its growing popularity in some quarters - such as Mexico City, where in the mid-term elections of 1949 and 1955 it garnered a considerable protest vote - meant that they could by no means ignore it (Camp, 1996, p. 177; Loaeza, 1999, ch. 3).

${ }^{23}$ Basail de la Vía \& Vertiz to director (January 10, 14, 1949), DFs-AGN. 
Therefore, as much as the BUDA's panismo, the group's role as a regular critic of government policy provided a motive for Carrillo Flores to side with Jenkins. As described above, the PRI of the 1950s was a party that tolerated little criticism, despite occasional declarations to the contrary and gestures towards a freer press, such as permitting the publication of the pluralistic and investigative magazine Siempre! On the occasion of general Treviño's remarkable speech at that year's PRI convention, the immediate response from the assembly was to try to shout him down (Krauze, 1997, p. 213f; Niblo, 1999, p. 237).

In the $1940 \mathrm{~s}$ and $50 \mathrm{~s}$, when government policy veered towards further state intervention in industry or in some other way dissatisfied them, BUDA or its proxies voiced criticism, whether via open letters to the press, interviews with journalists, or speeches at the annual convention of the Mexican Banking Association (АВM). Ugarte and Iturbide were prominent critics (Ángel, 2007, pp. 68-70). ${ }^{24}$ Eduardo Suárez, Treasury Minister from 1935 to 1946, would recall in his memoirs that in contrast to the Banco Nacional de México, which represented liberal principals and "tenía una actitud francamente amistosa y de cooperación con el gobierno", ${ }^{25}$ the Banco de Comercio was a very conservative institution, which under Ugarte's leadership limited itself to fostering the growth of existing companies rather than financing new ones, such as a developing nation like Mexico very much needed (Suárez, 2003, pp. 340-342).

Carrillo Flores would similarly recall that, unlike the Banco Nacional de México, which "históricamente representaba la posición de solidaridad con el gobierno", ${ }^{26}$ the Banco de Comercio "representaba la actitud de independencia y en ciertos momentos de oposición a la política monetaria de los gobiernos". ${ }^{27}$ In particular, Mario Domínguez and Salvador Ugarte would channel harsh criticisms of state policy through their representatives Iturbide and Escandón at the ABM conventions each spring. ${ }^{28}$ Like any cabinet member, Carrillo Flores' sensitivity to such criticism would have been heightened by its rarity in a public sphere that was almost always flattering of senior officials. Press coverage of the ABM conventions, which Treasury ministers regularly attended, typified this culture. Their speeches always generated the most attention and the headlines were effusive: "trascendental exposición", "sensacional discurso", "brillante síntesis", and so forth. ${ }^{29}$

At the ABM convention of 1953, the first of the Ruiz Cortines era, a heated discussion took place between bankers and functionaries following the government's passage of a new income tax law, which raised the tax on company dividends from 10 to $15 \%$ (Ángel, 2007, p. 71). Moreover, in marked contrast to the general flattery that met Carrillo Flores' inaugural speech, Iturbide questioned the feasibility of the minister's suggestion that Mexico's private capital market offer greater support for public works projects, given that its meagre size barely met the needs of the private sector. ${ }^{30}$

${ }^{24}$ Basail de la Vía \& Vertiz to director (January 10, 1949), DFs-AGN; Excélsior (April 29, 1950; April 29, 1951); Novedades (December 18, 1952); Archivos Económicos, Biblioteca Lerdo de Tejada (hereafter AE-BLT), N11185 (Iturbide).

25 "Showed a frankly amicable and cooperative attitude towards the government" [Author's translation].

26 "Historically reflected a position of solidarity with the government" [Author's translation].

27 "Represented an attitude of independence and occasionally opposition to state monetary policy" [Author's translation].

28 Carrillo (1983, pp. 9-12).

29 AE-BLT, DO3007 (1950) to DO3013 (1956).

${ }^{30}$ El Nacional (April 29, 1953); AE-BLT, DO3011. 
The convention of 1954 (April 25-28) was dominated by the peso devaluation that April 17. Carrillo Flores had deliberately scheduled it before the ABM was to convene. On April 20, the director of the DFS wrote a memo advising that speeches would be made by the four principal banking groups, starting with BUDA Group. Just before the event began, Iturbide set a combative tone by telling the press that the annual convention functioned as a national platform for the country's financial authorities, so that they might explain their actions and plans, the importance of which grew "si tomamos en cuenta que nuestros ensayos democráticos no nos han llevado todavía a un verdadero régimen parlamentario". ${ }^{11}$ In response to Carrillo Flores' opening-day speech, Iturbide urged the government to tackle the longstanding root causes of the devaluation, implying that it had been remiss for not doing so earlier. Carrillo Flores departed the convention so despondent at having failed to rally support for the devaluation that he offered Ruiz Cortines his resignation (which the president refused). ${ }^{32}$

Immediately following the devaluation, rumours arose that the Banco de Comercio was encouraging clients to transfer their deposits into dollars, thus effectively expressing its displeasure with the government once again. Carrillo Flores did not ascertain if the rumours were true, but he did find that prominent board member Trouyet, who owned a brokerage firm, had somehow got advance notice of the devaluation and bought US\$2 $500000 .{ }^{33}$

At the 1955 ABM convention, by unanimous vote and to prolonged applause, 500 bankers elected none other than Iturbide as their president (it was a one-year term). ${ }^{34}$ Whether the election of Mexico's most outspoken banker represented a vote of confidence in Iturbide due to his positions vis-à-vis the federal government, due to his opposition to the Jenkins-Espinosa takeover of the bank where he had made his name, or both, his coronation can hardly have improved his relationship with Carrillo Flores. ${ }^{35}$

Many years later, Espinosa's eldest daughter interviewed Carrillo Flores and they discussed her father's early difficulties at the Banco de Comercio. The former minister told her that some of the board members who had quit in the mass resignation of 1956 had visited him and tried to persuade him to intervene, arguing that Espinosa lacked sufficient experience to direct Mexico's second-largest bank. He added that Agustín Legorreta López, Banco Nacional de México CEo, on hearing that the Banco de Comercio was having boardroom difficulties, visited him and suggested that he expropriate the rival bank in order to allow him to buy it. But Carrillo Flores turned down both requests, after consulting with Ruiz Cortines. In apparent reference to both the BuDA Group and Legorreta, Carrillo Flores told the president: "aquí hay un punto de principio: no podemos permitir que un grupo declare que él es más fuerte que el gobierno y que le impone al gobierno, que el gobierno tome una intervención en un banco privado que no tiene derecho [...] a tomarla”. ${ }^{36}$

31 "If we take into account that our efforts at democracy have not yet led us to a truly parliamentary system" [Author's translation].

32 Castillo (1954a); Carrillo (1983, pp. 18, 21, 23f); El Universal (April 23, 1954); Novedades (April 27, 1954); AE-BLT, DO3011.

33 Carrillo (1983, pp. 17-20, 24); El Universal (April 27, 1954, p. 1).

34 ABC (April 27, 1955); La Prensa (April 28, 1955); AE-BLt, DO3012.

${ }^{35}$ On Iturbide as a critical ideologue of the banking sector, see Romero-Sotelo (2015, pp. 261-263).

36 "here is a point of principle: we cannot allow some group to declare that it's stronger than the government and lords over the government, or that the government intervenes in a private bank when it has no right...to do so" [Author's translation]. Carrillo (1983, pp. 32-34). In an interview of her own, Amparo Espinosa Rugarcía later claimed Carrillo Flores told her he had turned the BuDA Group down due to their affiliation to the PaN (Paxman, 2016, p. 415). There is no sign of this claim in the transcript, but he might have made it off-the-record. 
In sum, an accumulation of attitudes and episodes, ideological and personal, gave Carrillo Flores cause to side against BUDA in the Banco de Comercio takeover and to maintain his support for Espinosa when two key BUDA allies, Iturbide and Trouyet, departed the bank and when three of the quartet also quit. These factors also suggest why, at the same time, Carrillo Flores urged Ugarte to stay on: it was a way of dividing a group that he perceived to be not only oppositional to state-led capitalism, but arrogant, thereby weakening it as a political-economic force.

There was also undoubtedly a third rationale behind Carrillo Flores' decision to back Jenkins and Espinosa: personal assurances and negotiations made by the American himself. It is notable that while Jenkins gained his majority stake in early 1954, his partner Espinosa did not assume the position of director -and, for purposes of public visibility, owner of the bank- until at least twelve months later. The likeliest explanation for this delay is that Carrillo Flores and others in government were carefully considering how to respond to the takeover, which in turn would have prompted Jenkins to emphasize his loyalty to the regime, including via the provision of tangible favours, and to make assurances that he would maintain a low profile as owner or co-owner.

The first assurance came immediately, for in March he discussed the awkward matter of his majority ownership with Espinosa Yglesias and - as the poblano had anticipated- he agreed to initiate an exchange of assets that would reduce his holding in the bank (Espinosa, 2000, p. 27f). Starting in 1950, the two men had begun to divide the movie-theatre chain they co-owned into two separate enterprises: a theatre operating company, which retained the name coTsA, and a real estate company that owned the physical buildings and constructed new ones, called Compañía Constructora y Operadora de Inmuebles (CCOI); the latter was formally registered in 1953. Espinosa now suggested that he trade his $50 \%$ stake in ccor for Jenkins' 51 \% stake in the Banco de Comercio and Jenkins agreed. ${ }^{37}$

The companies were indeed roughly equal in worth. A few months later, Jenkins would value CCOI at 90000000 pesos, while the $10 \%$ stake in the Banco de Comercio that Espinosa bought from Senderos suggested a total valuation for the bank of around 82000000 pesos (Espinosa, 2000, p. 25f). ${ }^{38}$ However, Jenkins' $51 \%$ stake in the bank brought with it total control, while on the other hand, Espinosa's $50 \%$ stake in CCOI was predicated on a large amount of debt -to Jenkins. Ever since they had begun investing in movie theatres in 1938, Jenkins had made loans to Espinosa, allowing him equal partnership, which the poblano pledged to repay out of future profits. In 1954, due to the rapidity of the chain's expansion, Espinosa was heavily in debt to his partner; indeed, seven years later Espinosa would admit that he still owed Jenkins nearly 33000000 pe$\operatorname{sos}^{39}$ (this would be the factual basis of Jenkins' reported comment: "Sí es cierto [que Espinosa es dueño del banco], pero yo soy dueño de Espinosa Yglesias” ${ }^{40}$ ). As a result, the asset exchange was effected only in part: a substantial batch of Banco de Comercio shares remained in the American's possession until he died (Eustace, 2005; Hamilton, 1982, p. 296; Paxman, 2016, pp. 298-300,

${ }^{37}$ Jenkins to Espinosa (March 16, 1954), MEY; Libro 1, t. 2, núm. 28 (February 13, 1953), RPP-Puebla. As cotsA leased most of its theatres, CCOI owned a minority; 33 theatres were donated to the FMSJ in 1954. Several dozen further theatres, including those corresponding to Alarcón's Cadena de Oro, were donated subsequently; Libro de Actas, vol. 1, items 1 (November 17, 1954), pp. 3-6, 9 (May 10, December 27, 1956), FMSJ.

38 Jenkins to Carrillo Flores (July 2, 1954), transcribed in Trueblood (1988, pp. 22f); Libro de Actas, vol. 1, item 1 (November 17, 1954), FMSJ.

${ }^{39}$ Jenkins to Espinosa (March 16, 1954), MEY; Espinosa to Jenkins (February 16, 1961), transcribed in Trueblood (1988, p. 25).

40 “Yes, it's true [that Espinosa is the bank's owner], but I'm the owner of Espinosa Yglesias" [Author's translation]. 
412). The issue of Espinosa's indebtedness to Jenkins is omitted from Espinosa's memoir, his biography, and the official history of the bank (Águila et al., 2007; Ángel, 2007; Espinosa, 2000). Still, the 1954 exchange would have allowed Espinosa to communicate sincerely to Carrillo Flores that Jenkins was no longer majority owner.

Even on the surface, however, this exchange did not settle the issue of the bank's ownership. While Jenkins no longer held a majority of shares, he and Espinosa were publicly viewed as a single corporate entity, the Jenkins' Group (along with Alarcón). Who owned what shares within that entity was a somewhat nebulous matter, not least because of Jenkins' custom of registering his shareholdings via prestanombres; indeed, his name does not appear in the property registry entry of the CCOI. There thus remained the awkward issue of Jenkins' future association with the bank in the public mind, fomented by El Popular and other independent sources. ${ }^{41}$ There also remained the opposition of the powerful BuDa Group. So Jenkins made other moves to ingratiate himself with Carrillo Flores and show himself a useful ally of the state.

The very next month gave Jenkins such an opportunity, when the devaluation provoked a crisis of confidence at the Banco de Comercio, with many clients rushing to withdraw their deposits. There was even a rumour that the bank might be forced to close or that the state might take it over. The crisis coincided with the ABM convention in Acapulco, causing Iturbide to depart early and have his speech read by someone else. According to a DFs report (which described the American as the bank's principal shareholder), Jenkins offered the bank personal financing of 100000000 pesos -enough to cover some $20 \%$ of all demand deposits - to prevent the run on the bank from turning into a disaster. If the withdrawals had reached the point of draining the bank's cash reserves, a failure at the Banco de Comercio could have triggered a sector-wide crisis; in that sense, Jenkins' intervention was important to the economy as a whole. ${ }^{42}$

His deep pockets served the government more directly when Mexico's commitment to the Panamerican Highway, an international project designed to build a major route from Alaska to Panama, fell behind schedule for lack of funds. At some point Jenkins had provided a completion loan for the Mexico City to Querétaro stretch, and in 1954, at the personal request of president Ruiz Cortines and in the apparent absence of another contractor willing to step in, a company of his started to build a section of it (Paxman, 2016, p. 393).

This was also the year in which Jenkins' finally committed to a long-gestating plan to pledge his fortune to philanthropy. In part, the timing was reportedly a response to pressure, as the Ruiz Cortines government was unhappy with his history of tax evasion. But in part the timing also gave him a reason for direct correspondence with Carrillo Flores, as he needed permission to register his theatre company CCOI as the initial asset of a charitable foundation that would use the AngloSaxon model of donating the profits earned by the endowment.

Hitherto, philanthropy in Mexico had never used this model, so there was no statute allowing real estate to be operated for charitable purposes (Paxman, 2016, pp. 399-404). Jenkins first wrote to Carrillo Flores in July 1954, seeking his observations (i. e. intervention) in this matter. His letter stated his intention to donate to the foundation not only CCOI, but other assets and shares and, upon his death, almost the entire remainder of his fortune. ${ }^{43}$

${ }^{41}$ This indeed proved to be the case; see Opinión Pública (August, 1959, pp. 16-20); Time (December 26, 1960, p. 26); Ceceña (1963, p. 248f).

42 Castillo (1954b); Novedades, (April 29, 1954); Carrillo (1983, pp. 20, 24). Demand deposits totalled 476000 pesos at end 1953 and 479000 at end 1954 (Anuario Financiero de México, 1954; 1955).

43 Jenkins to Carrillo Flores (July 2, 1954), transcribed in Trueblood (1988, p. 22f). 
While the rest of their correspondence is apparently lost, Jenkins clearly obtained Carrillo Flores' approval, because the Fundación Mary Street Jenkins (FMSJ) was formally constituted before Puebla's Junta de Beneficencia in October 1954, with the CCOI movie theatres registered and notarized as its endowment. ${ }^{44}$ During its first six months of operation, through March 1955, the FMSJ started a scholarship programme for university students; began an initiative to turn Puebla's premier sports club into a non-profit; initiated plans for a Puebla City cancer hospital and orphanage; and pledged support (eventually 5000000 pesos, a third of the total cost) for a school for 6000 pupils in Puebla City. ${ }^{45}$

Finally, given the rich history of post-revolutionary crony capitalism, a potential fourth factor must be considered: Was Carrillo Flores bribed, either with a shareholding in the bank or otherwise? To date, no hint of such a transaction has emerged. Since Espinosa died in 2000, several scholars have written in depth about the Banco de Comercio, incorporating interviews with former directors and executives who worked alongside the poblano and others who fell out with him, and none have made such an accusation (Águila et al., 2007; Ángel 2007, 2012; Chavarín, 2010). The only remotely relevant detail is that in 1959 or 1960, upon the retirement of Ugarte, Espinosa offered Carrillo Flores the presidency of the bank, together with a handsome honorarium; the former minister, who was Mexico's ambassador to the United States at the time, declined out of a sense of patriotic duty to remain in Washington at a time of high tensions over Cuba. ${ }^{46}$ Espinosa's gesture, coming several years after he took control of the bank, suggests gratitude post facto, not a pay-off.

On March 24, 1955, the Banco de Comercio board convened for an extraordinary meeting. Carrillo Flores had at least a year in which to weigh up his right to reject the banks' change of ownership, a right afforded by both the $51 \%$ decree of 1944 and, at least implicitly, the banking law of 1941. That he chose not to intervene is affirmed by the fact that on this date the board approved Espinosa's wish to be named as director, ostensibly second in command to Ugarte, the 75-year old president, but effectively in charge (Ángel, 2007, p. 80f). Espinosa assumed the post a month later. More to the point, the approval was a coronation: a recognition, soon to be made public, that the poblano was in charge of Mexico's second-biggest bank. ${ }^{47}$

\section{Conclusion}

The change of ownership of the Banco de Comercio in 1954 cannot be explained in terms of business manoeuvres alone. If the law had been strictly observed, the Treasury would have obliged Jenkins to return $10 \%$ stake that Espinosa bought on his behalf to Senderos, on the grounds that it gave a foreigner majority control of a Mexican bank. Nor would it have been permissible for Espinosa to assume the shareholding, given that the poblano's severe indebtedness to the American effectively made him a financial dependent. The fact that the transaction was permitted -an ap-

\footnotetext{
${ }^{44}$ Fundación Mary Street Jenkins, Notaría Pública 13, Puebla, vol. 217, núm 14557 (October 18, 1954), FMSJ; Libro de Actas, vol. 1, item 1 (November 17, 1954), FMSJ.

${ }^{45}$ La Opinión, (December 5, 1954, p. 1, December 27, 1954, p. 1; January 12, 1957, p. 1); D. Palma Gutiérrez to director (June 9, 1964), exp. 100-19-4-64, leg. 1, pp. 12-15, DFS-AGN.

${ }^{46}$ Carrillo (1983, p. 14).

${ }^{47}$ El Universal (April 27, 1955, p. 1); El Popular (June 6, 1955, p. 1).
} 
proval signalled behind the scenes by the personal assurances of Carrillo Flores and other senior officials and in public by Espinosa's assumption of the bank's direction a year or so later- owed to the privileging of political considerations over the letter of the law.

Given methodological limitations and archival restrictions, historians have only occasionally grappled with the role of politics in the shaping of Mexican business. Hence, it is hard to gauge the typicality of the state's approval of the Jenkins-Espinosa takeover. But several other events during presidential term of Ruiz Cortines suggest that a politically-approved skirting of the law may well have been common to the trajectory of many of Mexico's biggest companies in the era of PRI hegemony. This is especially true of the monopolistic concentration of certain business sectors, in apparent contravention of the anti-monopoly law of 1934. That law was almost never enforced. ${ }^{48}$ However, its mere existence would have given the government a tool with which to exercise pressure upon actual or potential monopolists in exchange for favours.

As noted above, an already-dominant Jenkins Group was permitted to acquire Abelardo Rodríguez's movie theatres in 1957. A year later, Jenkins and his allies were reported to own or otherwise control $80 \%$ of Mexico's theatres. ${ }^{49}$ In 1955, Ruiz Cortines himself approved the merger of the country's three nascent television networks to produce Telesistema Mexicano. This monopoly, spearheaded by leading TV magnate Emilio Azcárraga Vidaurreta, contrasted with the competitive TV landscape elsewhere in Latin America (Fernández \& Paxman, 2021, pp. 79-82). A permissive attitude towards monopolistic concentration persisted in subsequent decades. For example, in the 1960s, corn flour producer Maseca bought out most of its rivals. In the 1970s, cigarette production became a near-duopoly in the hands of Cigarrera La Moderna and Cigatam. In the 1980s, the visa Group's Cervecería Cuauhtémoc merged with the Cervecería Moctezuma to create a duopolistic rival to the Modelo Group, while Cemex acquired closest rival Cementos Tolteca to become a quasi-monopoly (Baring Securities, 1991; Fuentes-Berain, 2007; Gauss \& Beatty, 2014; Gómez-Galvarriato, 2019).

In each case, the question of the potential benefit to the state arises. Clearly the rationales varied. The Banco de Comercio takeover was permitted as it allowed the government to undermine the PAN and fragment a prominent business clique that was critical of state-led development. The Jenkins Group movie-theatre monopoly was allowed to grow -first under Ávila Camacho and Alemán, then under Ruiz Cortines- because it solidified control of a major mass medium and propaganda conduit in the hands of party loyalists -though there are also signs that these presidents may have had a financial interest in the business-(Paxman, 2016, pp. 345, 426). The television monopoly facilitated the nationwide growth of an entertainment-cum-propaganda machine that similarly served the PRI's purposes.

In the cases of corn flour, cigarettes, beer, and cement, the motives for state complicity in monopolistic concentration await a thorough investigation. The convening of the beneficiaries of such selectively-permitted practices -by now, dollar billionaires- at the famous 1993 PRI fundraising dinner hosted by former Treasury minister Antonio Ortiz Mena is the most visible sign of a quid pro quo to have emerged to date (Oppenheimer, 1996, ch. 5). But it chiefly reflects a symbiosis in the long term. What other benefits had political elites gained in the short run? Were they monetary, and if so, were the benefits institutional (donations to the PRI or to a particular campaign) or

${ }^{48}$ Ley Orgánica del Artículo 28 Constitucional en Materia de Monopolios (August 3, 1934, section 2), Diario Oficial. According to Pérez-Miranda (1999, pp. 284-285), prior to its abrogation in 1992, the law was only applied once against an infringing party.

${ }^{49}$ Variety (December 3, 1958, p. 11). 
interpersonal (cash bribes, covert shareholdings)? Or were they intangible and ideological, as was the case with the Banco de Comercio approval? More sector-specific research is needed on these matters.

Finally, these episodes of favour-granting also raise important questions about the nature of Mexican entrepreneurialism. In sum, to what extent have Mexico's most successful companies depended on the vision and drive of their chief executives as opposed to the politicized and selective granting of legal waivers, tax breaks, tariff protections, contracts, and concessions? A deep analysis of entrepreneurialism in Mexico remains lacking.

\section{LIST OF REFERENCES}

Aguayo, S. (2001). La charola: Una historia de los servicios de inteligencia en México. México: Grijalbo.

Águila, M. T., Soler, M. y Suárez, R. (2007). Trabajo, fortuna y poder: Manuel Espinosa Yglesias: un empresario mexicano del siglo xx. México: Centro de Estudios Espinosa Yglesias.

Alexander, R. M. (2016). Sons of the Mexican Revolution: Miguel Alemán and his generation. Albuquerque: University of New Mexico Press.

Ángel, G. del (2007). BBVA Bancomer: 75 años de historia. México: BBVA Bancomer.

Ángel, G. del (2012). ¿Por qué BBVA Bancomer tiene una participación de mercado tan grande? Expansión a través de redes corporativas: Banco de Comercio 1932-1982. Revista de La Historia de La Economía y La Empresa.

Anuario Financiero de México [1941 to 1964] (1941-1964). México: Asociación de Banqueros de México.

Baring Securities (1991). Grupo Carso: Mexico’s Fastest-Growing Group. México.

Camp, R. A. (1989). Entrepreneurs and politics in twentieth-century Mexico. New York: Oxford University Press.

Camp, R. A. (1996). Politics in Mexico (2nd ed). New York: Oxford University Press.

Carrillo, A. (1983, February 11). Interview (A. Espinosa, Interviewer). Archivo Manuel Espinosa Yglesias (caja 46, exp. 5).

Castillo, L. (1954a, April 20). Memo. Federal Security Directorate, Archivo General de la Nación.

Castillo, L. (1954b, April 26). Memo. Federal Security Directorate, Archivo General de la Nación (exp. 9-232-954, leg. 1, h. 21).

Ceceña, J. L. (1963). El capital monopolista y la economía mexicana. México: Cuadernos Americanos.

Chavarín, R. A. (2010). Banca, grupos económicos y gobierno corporativo en México. México: Centro de Estudios Espinosa Yglesias.

Concheiro, E., Gutiérrez, A. y Fragosa, J. M. (1979). El poder de la gran burguesía. Ediciones de Cultura Popular.

Elizondo, C. (2001). La importancia de las reglas: Gobierno y empresario después de la nacionalización bancaria. México: Fondo de Cultura Económica.

Espinosa, M. (2000). Bancomer: Logro y destrucción de un ideal. México: Planeta.

Espinosa, M. (1946, April 15). Memo. Collection of Guillermo Puente, Querétaro, México.

Eustace, J. (2005, July 31). Interview [A. Paxman, Interviewer].

Fernández, C. y Paxman, A. (2021). El Tigre: Emilio Azcárraga y su imperio Televisa (4a. ed.). México: Grijalbo.

Fuentes-Berain, R. (2007). Oro gris: Zambrano, la gesta de CEMEX y la globalización en México. México: Aguilar/Raya en el Agua. 
Gauss, S. M. (2010). Made in Mexico: Regions, nation, and the state in the rise of Mexican industrialism, 1920s-1940s. University Park: Pennsylvania State University Press.

Gauss, S. M. \& Beatty, E. (2014). The world's beer: The historical geography of brewing in Mexico. In M. Patterson \& N. Hoalst-Pullen (Eds.), The Geography of Beer (pp. 57-65). Dordrecht: Springer Science.

Gómez-Galvarriato, A. (2019). Maseca-Gruma: The building of a corn flour and tortillas global emporium. Innovation or cronyism? Presented at the Business History Conference, Cartagena, Colombia.

González, L. (1979). Historia de la revolución mexicana, 1934-1940: Los artífices del cardenismo. México: El Colegio de México. DoI: 10.2307/j.ctv233ngk

Haber, S. H. (1991). Industrial concentration and the capital markets: A comparative study of Brazil, Mexico, and the United States, 1830-1930. The Journal of Economic History, 51(3), 559-580.

Hamilton, N. (1982). The limits of State autonomy: Post-revolutionary Mexico. Princeton: Princeton University Press.

Jacobo, E., Luna, M. y Tirado, R. (Eds.). (1989). Empresarios de México: Aspectos históricos, económicos e ideológicos. México: Universidad de Guadalajara.

Krauze, E. (1997). La presidencia imperial: Ascenso y caída del sistema político mexicano (1940-1996). México: Tusquets.

Loaeza, M. S. (1999). El Partido Acción Nacional: La larga marcha, 1939-1994: oposición real y partido de protesta. México: Fondo de Cultura Económica.

Maurer, N. (2002). The power and the money: The Mexican financial system, 1876-1932. Stanford: Stanford University Press.

Maxfield, S. (1990). Governing capital: International finance and Mexican politics. Ithaca: Cornell University Press.

Navarro, A. W. (2010). Political intelligence and the creation of modern Mexico, 1938-1954. University Park: Pennsylvania State University Press.

Niblo, S. R. (1995). War, diplomacy, and development: The United States and Mexico, 1938-1954. Wilmington: Scholarly Resources.

Niblo, S. R. (1999). Mexico in the 1940s: Modernity, politics, and corruption. Wilmington: Scholarly Resources.

Oppenheimer, A. (1996). Bordering on chaos: Mexico's roller-coaster journey toward prosperity. Boston: Little, Brown and Co.

Paxman, A. (2016). En busca del señor Jenkins: Dinero, poder y gringofobia en México. México: Debate/CIDE.

Paxman, A. (2018). Who Killed the Mexican Film Industry? The Decline of the Golden Age, 1946-1960. Estudios Interdisciplinarios de América Latina, 29(1), 9-33.

Pellicer, O. y Reyna, J. L. (1978). Historia de la revolución mexicana, periodo 1952-1960: El afianzamiento de la estabilidad política. México: El Colegio de México. Dor: 10.2307/j.ctv233pb3

Pérez-Miranda, R. (1999). Propiedad industrial y competencia en México: Un enfoque de derecho económico. México: Porrúa.

Pozas, R., y Luna, M. (Eds.). (1991). Las empresas y los empresarios en el México contemporáneo. México: Grijalbo.

Puente, G. (2018, June 1). Interview [A. Paxman, Interviewer].

Puente, L. (1969, May 28). Curriculum vitae. Collection of Guillermo Puente. 
Recio, G. (2004). Lawyers' contribution to business development in early twentieth-century Mexico. Enterprise \& Society, 5(2), 281-306. Dor: 10.1017/S1467222700013501

Recio, G. (2016). Don Eugenio Garza Sada: Ideas, acción, legado. México: Font.

Romero-Ibarra, M. E. (Ed.). (2006). Poder público y poder privado: Gobierno, empresarios y empresas: 1880-1980. México: Universidad Nacional Autónoma de México.

Romero-Sotelo, M. E. (2015). Aníbal de Iturbide Preciat. In L. Ludlow (Ed.), Grandes financieros mexicanos (pp. 259-267). México: LID.

Saragoza, A. (1988). The Monterrey elite and the Mexican State, 1880-1940. Austin: University of Texas Press.

Schneider, B. R. (2004). Business politics and the State in twentieth-century Latin America. Cambridge/New York: Cambridge University Press.

Senderos, M. (2006, Aug. 29). Interview [G. del Ángel, Interviewer].

Servín, E. (2001). Ruptura y oposición: El movimiento henriquista, 1945-1954. México: Cal y Arena.

Sherman, J. W. (1997). The Mexican right: The end of revolutionary reform, 1929-1940. Westport: Praeger.

Smith, B. T. (2018). The Mexican press and civil society, 1940-1976: Stories from the newsroom, stories from the street. Chapel Hill: University of North Carolina Press.

Story, D. (1986). Industry, the state, and public policy in Mexico. Austin: University of Texas Press.

Suárez, E. (2003). Comentarios y recuerdos: 1926-1946. Vol. I. México: Senado de la República.

Trejo, R. (2013). Carlos Slim: Vida y Obra. México: Quién es Quién.

Trueblood, B. (Ed.). (1988). Fundación Mary Street Jenkins. México: Fundación Mary Street Jenkins.

Valdés, F. (1997). Autonomía y legitimidad: Los empresarios, la política y el estado en México. México: Siglo Veintiuno Editores.

Vidal, G. (2000). Grandes empresas, economía y poder en México. México: Universidad Autónoma Metropolitana.

Zamora, S. (Ed.). (2004). Mexican law. Oxford/New York: Oxford University Press.

Zebadúa, E. (1994). Banqueros y revolucionarios: La soberanía financiera de México. México: El Colegio de México.

\section{Other sources}

$A B C$, Mexico City, Mexico.

Diario Oficial, Mexico City, Mexico.

El Popular, Mexico City, Mexico.

El Universal, Mexico City, Mexico.

Excélsior, Mexico City, Mexico.

La Opinión, Puebla, Mexico.

La Prensa, Mexico City, Mexico.

Opinión Pública, Mexico City, Mexico.

Novedades, Mexico City, Mexico.

Time, New York, United States.

Variety, New York, United States. 


\section{Archives}

Collection of Guillermo Puente, Querétaro, Mexico.

AE-Blt Archivos Económicos, Biblioteca Lerdo de Tejada, Secretaría de Hacienda y Crédito Público, Mexico City, Mexico.

DFS-Agn Dirección Federal de Seguridad, Archivo General de la Nación, Mexico City, Mexico. FMSJ Fundación Mary Street Jenkins, Puebla, Mexico.

Mey Manuel Espinosa Yglesias, Centro de Estudios Espinosa Yglesias, Mexico City, Mexico. RPP-Puebla Registro Público de la Propiedad, Puebla, Mexico. 